\title{
Effect of Nitrogen on Growth, Yield and Nutrient Uptake of Rice under Aerobic Condition
}

\author{
Neha Nandan*, D. K. Roy, Shashank Kumar and Ashok Kumar \\ Department of Agronomy, Dr. Rajendra Prasad Central Agricultural University, Pusa, \\ Samastipur, Bihar - 848 125, India \\ *Corresponding author
}

\section{A B S T R A C T}

A field experiment was undertaken during kharif of the year 2016 at the Research Farm of Dr. Rajendra Prasad Central Agricultural University, Pusa (Samastipur), Bihar. The experiment was conducted in split plot design having three levels of nitrogen in main plots

\section{Keywords}

aerobic rice, Yield,

N, P \& K uptake, B: $\mathrm{C}$ ratio

\section{Article Info}

Accepted:

15 January 2020

Available Online:

10 February 2020
$\left(\mathrm{N}_{1}-120 \mathrm{~kg} \mathrm{~N} / \mathrm{ha}, \mathrm{N}_{2}-140 \mathrm{~kg} \mathrm{~N} / \mathrm{ha}\right.$ and $\mathrm{N}_{3}-160 \mathrm{~kg} \mathrm{~N} / \mathrm{ha}$, ) and six weed management practices $\left(\mathrm{W}_{1}\right.$ - Pyrazosulfuron @ $25 \mathrm{~g} / \mathrm{ha}$ (20 DAS), W $\mathrm{W}_{2}$-Bispyribac sodium @ $25 \mathrm{~g} / \mathrm{ha}$ (20 DAS), W 3 -Pyrazosulfuron @ 25g/ha + Bispyribac sodium @ 25g/ha (20 DAS), W 4 Pendimethalin@1000g/ha (PE)+ $\mathrm{W}_{3}$ (20 DAS), $\mathrm{W}_{5}$-Weed free (2 Hand weeding at 20 \& 40 DAS) and W6-Weedy check) in sub plots, replicated thrice with Abhishek as the test variety. Higher level of nitrogen i.e. $160 \mathrm{Kg} / \mathrm{ha}$ exhibited better expression in respect of growth and yield attributes than the other two levels and it was somehow also comparable to $140 \mathrm{~kg} \mathrm{~N} / \mathrm{ha}$. The better performance in terms of growth and yield attributed were reflected correspondingly in grain and straw yield however harvest index didn't show any significant variation due to nitrogen treatments. Nutrient uptake by crop was higher in 160 $\mathrm{kg} \mathrm{N} / \mathrm{ha}$ than other two lower doses. Amongst the two lower doses of nitrogen, $140 \mathrm{~kg}$ $\mathrm{N} / \mathrm{ha}$ had an edge over $120 \mathrm{~kg} \mathrm{~N} / \mathrm{ha}$. The most glaring part of results rested in its economic studies, wherein treatment with $160 \mathrm{Kg} \mathrm{N} /$ ha fetched higher gross returns, net return and finally B:C ratio than other two doses.

\section{Introduction}

Rice is the world's most important crop and more than half of the world's population depends on it for food, calories and protein especially in developing countries however it is the biggest user of freshwater. Rice production consumes about $30 \%$ of all fresh water used worldwide. Flood-irrigated rice uses two to three times more water than other cereal crops such as wheat and maize. In wet rice cultivation, it takes 2000 to 3000 liters of water to produce $1 \mathrm{~kg}$ of rice. However, scarcity of freshwater resources has threatened the production of the floodirrigated rice crop (IWMI, 2000). By 2025, 15 out 75 million hectare of Asia's floodirrigated rice crop will experience water shortage (Tuong and Bouman, 2003). So, alternative to transplanting could be aerobic 
rice because it requires less water, less labour and capital.

Aerobic rice system, wherein the crop is established via direct seeding in non- puddled, non flooded fields are the most promising approach for saving water (Tuong and Bhushan et al., 2007). Aerobic rice can reduce water application by $44 \%$ relative to conventionally transplanted system by reducing percolation, seepage and evaporative loss (Bouman et al., 2005). Direct seeded culture has become increasingly important in rice cultivation due to scarcity of farm labour and higher water requirement and higher production cost of transplanted rice (Azmi and Baki, 2007). Direct seeded rice needs only $34 \%$ of the total labour requirement and saves $27 \%$ of the total cost of the transplanted crop (Mishra and Singh, 2011). Direct seeding of rice also allows early establishment of the succeeding wheat crop. Aerobic rice system is subjected to much higher weed pressure than conventional puddled transplanted system (Rao et al., 2007) in which weeds are suppressed by standing water. Weeds are the most severe constraints and timely weed management is crucial for increasing the productivity of rice under aerobic condition. Uncontrolled weeds reduce the yield by $96 \%$ in dry direct-seeded rice and $61 \%$ in wet direct-seeded rice (Maity and Mukherjee, 2008). During peak period, the availability of labour is becoming a serious problem by time in all parts of country. So, Herbicides are used successfully for weed control in rice fields for rapid and effective result, easier to application and low cost involvement in comparison to the traditional methods of hand weeding.

Nitrogen is one of the most important yield limiting nutrients affecting growth and quality in rice system (De Datta et al., 1988; Khan et al., 2012) and accounts for $67 \%$ of the total applied fertilizers worldwide (Vlek and
Byrnes, 1986). Nitrogen use efficiency (NUE) of rice is usually low due to volatilization, runoff, denitrification and leaching losses (Modgal et al., 1995). Moreover, direct seeded rice soils are often exposed to dry and wet conditions and difference in $\mathrm{N}$ dynamics and losses pathways often results in different fertilizer recoveries in aerobic soils (De Datta and Buresh, 1989). Even high and nonsynchronous applied nitrogen may limit grain yield due to limited grain filling rate by decrease in post anthesis assimilates translocation (Zhang et al., 2009). Thus, Nitrogen and weeds are the two important factors that influence the productivity of rice under aerobic condition in tropical Asia.

\section{Materials and Methods}

The experiment was laid out in Nursery Jhilli Field at Dr. Rajendra Prasad Central Agricultural University, Pusa farm situated on the southern bank of the river Budhi Gandak in Samastipur district (25.590 N and 84.400 E and $52.3 \mathrm{~m}$ above the mean sea level). Soil of the experimental site was calcareous (clay loam) and relatively low fertile with $\mathrm{pH} 8.4$, organic carbon $0.43 \%$, available NPK 209, 20.8 and $116.4 \mathrm{~kg} / \mathrm{ha}$ respectively. The total rainfall of $770.7 \mathrm{~mm}$ was recorded during cropping period of 2016. The experiment was conducted during kharif of 2016 in split plot design with three replications. The factors under study comprised three Nitrogen levels i.e. $\mathrm{N}_{1}-120 \mathrm{~kg} \mathrm{~N} / \mathrm{ha}, \mathrm{N}_{2}-140 \mathrm{~kg} \mathrm{~N} / \mathrm{ha}, \mathrm{N}_{3}-160$ $\mathrm{kg} \mathrm{N} / \mathrm{ha}$ in main plots and 6 weed management treatments on rice under aerobic condition i.e. $W_{1}$ - Pyrazosulfuron@25 g/ha (20 DAS), $W_{2}$ - Bispyribac sodium @ $25 \mathrm{~g} / \mathrm{ha}$ (20 DAS), $\mathrm{W}_{3}$ - Pyrazosulfuron @ $25 \mathrm{~g} / \mathrm{ha}+$ Bispyribac sodium@25 g/ha (20 DAS), W4 Pendimethalin@1000g/ha (PE) + W 3 (20 DAS), $\mathrm{W}_{5^{-}}$Hand weeding at $20 \& 40$ DAS, $\mathrm{W}_{6^{-}}$weedy check in sub-plots. The variety used was Abhishek. It is long duration (110115 days) rice variety suitable for irrigated 
condition. Seed rate was $40 \mathrm{~kg} / \mathrm{ha}$ and treated seeds were sown in rows with $20 \mathrm{~cm}$ row to row spacing. Half dose of nitrogen (as per the treatments through urea) and full dose of phosphorus and potash (50-30 $\mathrm{kg} \mathrm{P}_{2} \mathrm{O}_{5}-\mathrm{K}_{2} \mathrm{O} /$ ha through SSP and MOP) were applied as basal dose at the time of sowing and remaining half dose of nitrogen was applied in two equal split at 30 and 60 DAS i.e. at tillering and panicle initiation stage. Herbicides were applied with the help of Knapsack sprayer fitted with flat fan nozzle. The crop was manually harvested and threshed in the third week of November. Data were recorded on weeds, growth attributes, yield and economics of rice crop. The process of estimation of $\mathrm{N}, \mathrm{P} \& \mathrm{~K}$ uptake are mentioned below:

\section{Nutrient uptake}

\section{Nitrogen uptake}

The nitrogen content in plant was determined by Kjeldahl's method (Jackson, 1973). The grain and straw were separated and then grinded. The grinded material was digested in concentrated sulphuric acid using copper sulphate and potassium sulphate mixture as catalyst. The digested material was then distilled with 40 percent sodium hydroxide and distillate was collected in boric acid containing the mixed indicator. The content was estimated by titrating the distillate against N/20 sulphuric acid. The nitrogen uptake was calculated by multiplying the dry weight with nitrogen content. In order to get total uptake of nitrogen, the uptake values for grain and straw were added together.

\section{Phosphorus uptake}

Total phosphorus uptake was determined in the extract by Vanedo molybdate yellow color method (Jackson, 1973). The optical density (OD) was measured with photoelectric colorimeter at $470 \mathrm{~nm}$. The content was estimated with calibration curve. The phosphorous uptake by grain and straw per hectare was calculated with the help of per cent value of phosphorus and yield of grain and straw. In order to get uptake of phosphorous, the uptake value for grain and straw were added together plot wise.

\section{Potassium uptake}

The potassium content was determined with the help of flame photometer (Jackson, 1973) and was estimated with calibration curve. Total uptake of potassium by rice grain and straw was calculated by multiplying their relative contents with yield of grain \& straw and values were added to know the total uptake of potassium in $\mathrm{kg} / \mathrm{ha}$.

The Crop Growth Rate (CGR) were calculated by using following formulae:

$\operatorname{CGR}\left(\mathrm{g} / \mathrm{m}^{2} /\right.$ day $)=\mathrm{W}_{2}-\mathrm{W}_{1} / \mathrm{t}_{2}-\mathrm{t}_{1}$

Where, $\mathrm{W}_{1} \& \mathrm{~W}_{2}$ are plant dry weights $\left(\mathrm{g} / \mathrm{m}^{2}\right)$ at time $\mathrm{t}_{1} \& \mathrm{t}_{2}$ respectively.

\section{Results and Discussion}

The plant height was significantly influenced by different nitrogen levels except at 30 DAS, where the application of $160 \mathrm{~kg} \mathrm{~N} /$ ha caused the significant increase in plant height over $120 \mathrm{~kg} \mathrm{~N} / \mathrm{ha}$ but it was at par with $140 \mathrm{~kg}$ N/ha. The other growth characters viz. number of tillers/m row length, dry matter production at progressive growth stages, and crop growth rates were also affected significantly due to different nitrogen levels. However, nitrogen level of $160 \mathrm{~kg} / \mathrm{ha}$ significantly had better growth expression than other two nitrogen levels. Nitrogen level of $120 \mathrm{~kg} \mathrm{~N} / \mathrm{ha}$ had significantly the lowest values for all these growth characters. In the present investigation number of panicles/m 
row length, number of spikelet per panicle, number of fertile spikelet per panicle and 1000-grain weight was the four yield attributes studied. The plots with $160 \mathrm{~kg} \mathrm{~N} / \mathrm{ha}$ had significantly the best expression in term of all the four yield attributes. Nitrogen, Phosphorus and Potassium uptake by crop were affected significantly due to different nitrogen levels and weed management practices. Quite in league with the performances as regards growth and development, the treatment comprised of 160 $\mathrm{kg} \mathrm{N} / \mathrm{ha}$ out classed the other two treatments in respect of gross return, net return as well as $\mathrm{B}$ : $\mathrm{C}$ ratio.

\section{Effect on growth characters}

The rice plants growing under treatment with $120 \mathrm{~kg} \mathrm{~N} / \mathrm{ha}$ had the shortest plants. This trend was there right from the vegetative, logvegetative and reproductive phases. Two other nitrogen levels i.e. $140 \mathrm{~kg} \mathrm{~N} / \mathrm{ha}$ and 160 $\mathrm{kg} \mathrm{N} / \mathrm{ha}$ fared equally well in this regard. However, treatment with $140 \mathrm{~kg} \mathrm{~N} / \mathrm{ha}$ (42.48, $75.93,103.88 \& 107.52 \mathrm{~m}$ at $30,60,90 \mathrm{DAS}$ $\&$ At harvest respectively) had an edge of 160 $\mathrm{kg} \mathrm{N} / \mathrm{ha}(44.38,78.80,109.10 \& 112.63 \mathrm{~m}$ at 30, 60, 90 DAS \& At harvest respectively) though not attaining a difference adequate to be termed as significant. Nitrogen is associated with protoplasm synthesis and vigorous vegetative growth due to increased cell division and cell elongation. Hence, application of nitrogen resulted in significant increase in plant height at early stages of crop growth. Similar findings were reported by Maheswari et al., (2008) and Sathiya and Ramesh (2009).

Total number of tillers /meter row length counted at 30, 60, 90 DAS and at harvest (39.05, 92.45, $76.77 \& 74.93$ respectively) was recorded significantly higher with $160 \mathrm{~kg}$ $\mathrm{N} / \mathrm{ha}$. Total number of tillers per meter row length tended to increase up to 60 DAS and beyond which declined towards harvest. Increasing levels of nitrogen progressively enhanced the total number of tillers at all the stages of observations and it was due to more nitrogen supply at active tillering stages. These results were in conformity with the findings of Jadhav et al., (2006).

Dry matter production of aerobic rice tended to increase progressively with an advance in the age of the crop up to harvest. Among the different nitrogen levels tried, highest dry matter production $(156.10,462.40,677.52 \&$ $842.50 \mathrm{~g} / \mathrm{m}^{2}$ at $30,60,90$ DAS and at harvest respectively) of aerobic rice was produced with the application of $160 \mathrm{~kg} \mathrm{~N} / \mathrm{ha}$ which was however significantly higher than that of other treatments. Lowest dry matter production was recorded with $120 \mathrm{~kg} \mathrm{~N} / \mathrm{ha}$. This might be due to cumulative effect of photosynthesis due to taller plants with more number of tillers because of increased availability of vital nutrients led to increased dry matter production. This positive effect of nitrogen on dry matter has been documented earlier by Devi and Sumathi (2011).

\section{Effect on yield attributes and yield}

The plots with $160 \mathrm{~kg}$ N/ha had significantly the best expression in term of all the four yield attributes i.e. number of panicles/m row length, number of spikelet per panicle, number of fertile spikelet per panicle and 1000-grain weight. The treatment next in order was comprised of $140 \mathrm{~kg} \mathrm{~N} / \mathrm{ha}$. The treatment with $160 \mathrm{~kg} \mathrm{~N} / \mathrm{ha}$ had the maximum panicles/m row length (71.41) maximum number of spikelet/panicle (140), maximum number of fertile spikelet per panicle (121) and the heaviest test weight (1000-grain weight of $24.65 \mathrm{~g}$ ). Commensurating with the performances in terms of yield attributes, both grain yield and straw yield too were the maximum (36.22 and $48.03 \mathrm{q} / \mathrm{ha})$ under treatment having $160 \mathrm{~kg} \mathrm{~N} / \mathrm{ha}$. However, the 
yields (grain and straw) obtained under 140 $\mathrm{kg} \mathrm{N} / \mathrm{ha}$ fared equally well (33.95 \& 44.25 $\mathrm{q} / \mathrm{ha}$ ) with regard to yield parameters establishing parity with $160 \mathrm{~kg}$ N/ha.

The yield was better due to less competition, and comparatively better availability of inputs involved in manufacture of building blocks for plant bodies. Simply one fact may be added here that the yield and yield attributes are more prone to weed competition than growth parameters as the growing meristematic tissues in rice plants remains below the ground level for greater part of vegetative growth. Whereas, the growing point in rice comes above the ground level and face more severe competition with weeds when yield attributes form in the plant body (Evans, 1979). Lower harvest index under weedy check condition may be explained on the basis that the menace of weeds go an increasing with increase in age. Hence, the vegetative growth was affected comparatively less. The results with regard to yield attributes and yield having developed under the influence of different nitrogen levels are in close conformity with the results reported earlier from Thimmegowda et al., (2009).

\section{Effect on nutrient uptake}

Uptake of $\mathrm{N}, \mathrm{P}$ and $\mathrm{K}$ were the maximum under treatment with $160 \mathrm{~kg}$ N/ha (70.29, $14.82 \& 64.30 \mathrm{~kg} / \mathrm{ha}$ respectively). Treatment with $140 \mathrm{~kg} \mathrm{~N} / \mathrm{ha}(64.58,12.24 \& 57.70 \mathrm{~kg} / \mathrm{ha}$ respectively) was the next in order. The least uptake of $\mathrm{N}, \mathrm{P}$ and $\mathrm{K}$ were recorded in the plots having $120 \mathrm{~kg} \mathrm{~N} / \mathrm{ha}$. There is not much to explain the behaviour of treatments as crop uptake is directly a function of biological yield.

The plots giving higher biological yields exhibited higher nutrient uptake and so on in other cases. Similarly, as the treatment with $160 \mathrm{~kg} \mathrm{~N} / \mathrm{ha}$ offered greater opportunity to crop to come up and grow, their weeds took up a lion's share of nutrients from the plots. This was mainly due to better control of weeds during active crop growth stages which helps in minimizing the crop weed competition and help the crop to utilize more nitrogen and other nutrients and led to better crop growth. Lower nutrient uptake might be due to severe competition offered by weeds for nutrients throughout the crop growth period which suppress the crop and severely affecting the crop growth. This result was in conformity with Singh and Tripathi (2007).

\section{Effect on economic aspects of rice cultivation}

Quite in league with the performances as regards growth and development, the treatment comprised of $160 \mathrm{~kg} \mathrm{~N} / \mathrm{ha}$ out classed the other two treatments in respect of gross return, net return as well as B: $\mathrm{C}$ ratio. The above mentioned treatment earned a net return of $\square 31,645 /$ ha with a $B$ : C ratio of 1.09. As against this, the treatment with 140 $\mathrm{kg} \mathrm{N} /$ ha fetched a net return of $\square 27,989 /$ ha concerning a $\mathrm{B}$ : $\mathrm{C}$ ratio of 0.97 . These two nitrogen levels were superior to $120 \mathrm{~kg} \mathrm{~N} / \mathrm{ha}$ which realized a net return of $\square 23,927 /$ ha having a $\mathrm{B}$ : $\mathrm{C}$ ratio of 0.84 .

The treatment with $160 \mathrm{~kg} \mathrm{~N} / \mathrm{ha}$, however, was adjudged comparable to the treatment with $140 \mathrm{~kg} \mathrm{~N} / \mathrm{ha}$, but was significantly superior to $120 \mathrm{~kg} \mathrm{~N} / \mathrm{ha}$ with regard to gross return, net return and $\mathrm{B}$ : $\mathrm{C}$ ratio. It is a fact that higher grain yield as well as straw yield obviously resulting in higher net return. Thus, the economic aspect virtually remains a reflection of economic yield and guide naturally the treatments found superior in economic yields were also superior in return and benefit: cost ratio. The findings of this investigation as regards economic aspects are quite in agreement with those reported by Devi and Sumathi (2011). 
Table.1 Effect of different treatments on plant height $(\mathrm{cm})$ and No. tillers/m row length at different stages of crop growth

\begin{tabular}{|c|c|c|c|c|c|c|c|c|}
\hline \multirow[t]{2}{*}{ Treatments } & \multicolumn{4}{|c|}{ Plant height (cm) } & \multicolumn{4}{|c|}{ No. of tillers/m row length } \\
\hline & 30 DAS & 60 DAS & 90 DAS & At harvest & 30 DAS & 60 DAS & 90 DAS & At harvest \\
\hline \multicolumn{9}{|l|}{ Nitrogen levels } \\
\hline $\mathrm{N}_{1}-120 \mathrm{~kg} \mathrm{~N} / \mathrm{ha}$ & 39.70 & 72.78 & 97.85 & 102.73 & 34.03 & 78.13 & 66.18 & 64.70 \\
\hline$N_{2}-140 \mathrm{~kg}$ N/ha & 42.48 & 75.93 & 103.88 & 107.52 & 36.12 & 86.20 & 69.60 & 70.47 \\
\hline$N_{3}-160 \mathrm{~kg} N / \mathrm{ha}$ & 44.38 & 78.80 & 109.10 & 112.63 & 39.05 & 92.45 & 76.77 & 74.93 \\
\hline SEm \pm & 0.77 & 0.23 & 0.55 & 0.50 & 0.41 & 0.58 & 0.32 & 0.43 \\
\hline $\mathrm{CD}(\mathrm{P}=0.05)$ & 3.09 & 0.91 & 2.22 & 2.00 & 1.64 & 2.34 & 1.29 & 1.74 \\
\hline \multicolumn{9}{|l|}{ Weed management } \\
\hline $\begin{array}{l}\text { W } 1 \text { Pyrazosulfuron @ } 25 \\
\text { g/ha }(20 \text { DAS) }\end{array}$ & 40.13 & 73.70 & 98.63 & 105.03 & 35.30 & 78.90 & 59.83 & 68.57 \\
\hline $\begin{array}{l}\text { W }_{2} \text { - Bispyribac sodium @ } \\
25 \text { g/ha }(20 \text { DAS })\end{array}$ & 42.93 & 76.90 & 107.27 & 110.80 & 37.43 & 89.63 & 75.43 & 74.97 \\
\hline $\begin{array}{l}\text { W3-Pyrazosulfuron @ } 25 \mathrm{~g}+ \\
\text { Bispyribac sodium @ } 25 \mathrm{~g} \\
\text { (tank mix) (20 DAS) }\end{array}$ & 44.50 & 78.90 & 110.57 & 113.00 & 38.93 & 94.57 & 78.40 & 77.33 \\
\hline $\begin{array}{l}\mathrm{W}_{4} \text { - Pendimethalin @1000 } \\
\text { g/ha }(\mathrm{PE}) f b \mathrm{~W}_{3}\end{array}$ & 45.50 & 80.07 & 112.87 & 115.17 & 40.53 & 98.37 & 80.97 & 79.73 \\
\hline $\begin{array}{l}W_{5}-\text { Weed free ( } 2 \text { Hand } \\
\text { weeding at } 20 \text { and } 40 \text { DAS })\end{array}$ & 46.73 & 81.67 & 115.17 & 117.63 & 41.43 & 101.40 & 84.53 & 82.43 \\
\hline$W_{6}-$ Weedy check & 33.33 & 63.80 & 77.17 & 84.13 & 35.30 & 78.90 & 59.83 & 68.57 \\
\hline SEm \pm & 0.61 & 0.73 & 0.62 & 0.88 & 37.43 & 89.63 & 75.43 & 74.97 \\
\hline $\mathrm{CD}(\mathrm{P}=\mathbf{0 . 0 5})$ & 1.76 & 2.08 & 1.79 & 2.55 & 38.93 & 94.57 & 78.40 & 77.33 \\
\hline Interaction (NXW) & NS & NS & NS & NS & NS & NS & NS & NS \\
\hline
\end{tabular}


Table.2 Effect of different treatments Plant dry matter production $\left(\mathrm{g} / \mathrm{m}^{2}\right)$ and Crop Growth Rate $\left(\mathrm{g} / \mathrm{m}^{2} /\right.$ day)

\begin{tabular}{|c|c|c|c|c|c|c|c|c|}
\hline \multirow[t]{2}{*}{ Treatments } & \multicolumn{4}{|c|}{ Plant dry matter production $\left(\mathrm{g} / \mathrm{m}^{2}\right)$} & \multicolumn{4}{|c|}{ Crop Growth Rate (g/m²/day) } \\
\hline & 30 DAS & 60 DAS & 90 DAS & At harvest & 30 DAS & 60 DAS & 90 DAS & At harvest \\
\hline \multicolumn{9}{|l|}{ Nitrogen levels } \\
\hline $\mathrm{N}_{1}-120 \mathrm{~kg} \mathrm{~N} / \mathrm{ha}$ & 147.66 & 453.06 & 646.69 & 724.33 & 4.92 & 10.18 & 6.45 & 2.59 \\
\hline $\mathrm{N}_{2}-140 \mathrm{~kg} \mathrm{~N} / \mathrm{ha}$ & 152.95 & 458.65 & 664.58 & 782.00 & 5.09 & 10.19 & 6.86 & 3.91 \\
\hline $\mathrm{N}_{3}-160 \mathrm{~kg} \mathrm{~N} / \mathrm{ha}$ & 156.10 & 462.40 & 677.52 & 842.50 & 5.20 & 10.21 & 7.17 & 5.50 \\
\hline SEm \pm & 0.34 & 0.32 & 0.40 & 4.47 & 0.01 & 0.02 & 0.01 & 0.14 \\
\hline $\mathrm{CD}(\mathrm{P}=0.05)$ & 1.38 & 1.33 & 1.63 & 18.00 & 0.05 & NS & 0.03 & 0.57 \\
\hline \multicolumn{9}{|l|}{ Weed management } \\
\hline $\begin{array}{l}\text { W1 . Pyrazosulfuron @ } \\
25 \text { g/ha (20 DAS) }\end{array}$ & 148.47 & 454.90 & 672.83 & 735.33 & 4.95 & 10.22 & 7.26 & 2.08 \\
\hline $\begin{array}{l}\text { W } \text {. Bispyribac sodium } \\
\text { @ } 25 \text { g/ha (20 DAS })\end{array}$ & 151.67 & 458.14 & 678.21 & 796.00 & 5.06 & 10.22 & 7.34 & 3.93 \\
\hline $\begin{array}{l}\text { W }_{3-} \text { Pyrazosulfuron } \\
\text { @ } 25 \text { g }+ \text { Bispyribac } \\
\text { sodium @ 25g (tank } \\
\text { mix) (20 DAS) }\end{array}$ & 154.51 & 461.65 & 686.31 & 831.67 & 5.15 & 10.24 & 7.49 & 4.85 \\
\hline $\begin{array}{l}\mathrm{W}_{4} \text { - } \text { Pendimethalin } \\
@ 1000 \mathrm{~g} / \mathrm{ha}(\mathrm{PE}) f b \mathrm{~W}_{3}\end{array}$ & 157.47 & 465.52 & 692.88 & 862.33 & 5.25 & 10.24 & 7.58 & 5.65 \\
\hline $\begin{array}{l}W_{5}-\text { Weed free }(2 \\
\text { Hand weeding at } 20 \& \\
40 \text { DAS })\end{array}$ & 161.65 & 468.89 & 700.51 & 900.33 & 5.39 & 10.27 & 7.72 & 6.66 \\
\hline $\mathrm{W}_{6}-$ Weedy check & 139.29 & 439.11 & 546.85 & 572.00 & 4.64 & 9.99 & 3.59 & 0.84 \\
\hline SEm \pm & 0.68 & 0.65 & 0.60 & 9.26 & 0.02 & 0.02 & 0.02 & 0.31 \\
\hline $\mathrm{CD}(\mathrm{P}=\mathbf{0 . 0 5})$ & 1.96 & 1.77 & 1.74 & 26.88 & 0.07 & 0.06 & 0.08 & 0.91 \\
\hline Interaction (NXW) & NS & NS & NS & NS & NS & NS & NS & NS \\
\hline
\end{tabular}


Table.3 Effect of different treatments on yield and its attributes

\begin{tabular}{|c|c|c|c|c|c|c|c|c|}
\hline Treatments & $\begin{array}{c}\text { No. of } \\
\text { panicles/m row } \\
\text { length }\end{array}$ & $\begin{array}{c}\text { No. of } \\
\text { spikelet/panicle }\end{array}$ & $\begin{array}{l}\text { No. of fertile } \\
\text { grains/panicle }\end{array}$ & $\begin{array}{l}\text { Grain } \\
\text { filling\% }\end{array}$ & $\begin{array}{l}\text { 1000-grain } \\
\text { weight }(g)\end{array}$ & $\begin{array}{l}\text { Grain } \\
\text { yield } \\
\text { (q/ha) }\end{array}$ & $\begin{array}{l}\text { Straw } \\
\text { yield } \\
(\mathbf{q} / \mathbf{h a}))\end{array}$ & $\begin{array}{l}\text { Harvest } \\
\text { index } \\
(\%)\end{array}$ \\
\hline \multicolumn{9}{|l|}{ Nitrogen levels } \\
\hline$N_{1}-120 \mathrm{~kg} \mathrm{~N} / \mathrm{ha}$ & 61.45 & 127 & 113 & 89 & 23.72 & 31.30 & 41.13 & 43.00 \\
\hline $\mathrm{N}_{2}-140 \mathrm{~kg} \mathrm{~N} / \mathrm{ha}$ & 67.68 & 133 & 117 & 88 & 24.14 & 33.95 & 44.25 & 43.24 \\
\hline$N_{3}-160 \mathrm{~kg} N / \mathrm{ha}$ & 71.41 & 140 & 121 & 86 & 24.65 & 36.22 & 48.03 & 42.92 \\
\hline SEm \pm & 1.24 & 0.45 & 0.50 & & 0.25 & 0.65 & 0.48 & 0.77 \\
\hline $\mathrm{CD}(\mathrm{P}=\mathbf{0 . 0 5})$ & 5.01 & 2 & 2 & & NS & 2.64 & 1.92 & NS \\
\hline \multicolumn{9}{|l|}{ Weed management } \\
\hline $\begin{array}{l}\text { W1 - Pyrazosulfuron@ } 25 \text { g/ha } \\
(20 \text { DAS) }\end{array}$ & 62.14 & 135 & 116 & 86 & 23.68 & 32.07 & 41.47 & 43.56 \\
\hline $\begin{array}{l}\text { W2 - Bispyribac sodium @ } 25 \\
\text { g/ha (20 DAS) }\end{array}$ & 69.33 & 137 & 120 & 88 & 24.01 & 34.93 & 44.67 & 43.89 \\
\hline $\begin{array}{l}\text { W }_{3} \text { - Pyrazosulfuron @25 g + } \\
\text { Bispyribac sodium @ 25g (tank } \\
\text { mix) (20 DAS) }\end{array}$ & 72.02 & 140 & 122 & 87 & 24.44 & 36.40 & 46.77 & 43.79 \\
\hline $\begin{array}{l}\mathrm{W}_{4} \text { - Pendimethalin @1000 g/ha } \\
\text { (PE) } f b \mathrm{~W}_{3}\end{array}$ & 76.14 & 143 & 124 & 88 & 24.70 & 37.50 & 48.73 & 43.51 \\
\hline $\begin{array}{l}W_{5}-\text { Weed free }(2 \text { Hand } \\
\text { weeding at } 20 \text { and } 40 \text { DAS })\end{array}$ & 78.22 & 146 & 126 & 86 & 24.85 & 39.07 & 50.97 & 43.44 \\
\hline $\mathrm{W}_{6}$ - Weedy check & 43.22 & 98 & 93 & 95 & 23.33 & 22.97 & 34.23 & 40.14 \\
\hline SEm \pm & 0.67 & 0.80 & 0.71 & & 0.31 & 0.67 & 0.70 & 0.73 \\
\hline $\mathrm{CD}(\mathrm{P}=0.05)$ & 1.95 & 2 & 2 & & 0.89 & 1.95 & 2.04 & 2.11 \\
\hline Interaction (NXW) & NS & NS & NS & & NS & NS & NS & NS \\
\hline
\end{tabular}


Table.4 Effect of different treatments on NPK uptake (kg/ha) by Crop, gross return ( $\square / \mathrm{ha}$ ), net return ( $\square$ /ha) and B: C ratio

\begin{tabular}{|c|c|c|c|c|c|c|}
\hline \multirow[t]{2}{*}{ Treatments } & \multicolumn{3}{|c|}{ NPK uptake by crop (kg/ha) } & \multirow{2}{*}{$\begin{array}{c}\text { Gross return } \\
\text { ( } \square / \text { ha) }\end{array}$} & \multirow{2}{*}{$\begin{array}{l}\text { Net return } \\
\quad(\square / \mathbf{h a})\end{array}$} & \multirow[t]{2}{*}{ B: C ratio } \\
\hline & N uptake (kg/ha) & P uptake (kg/ha) & K uptake (kg/ha) & & & \\
\hline \multicolumn{7}{|l|}{ Nitrogen levels } \\
\hline $\mathrm{N}_{1}-120 \mathrm{~kg} \mathrm{~N} / \mathrm{ha}$ & 58.88 & 10.18 & 52.00 & 52,360 & 23,927 & 0.84 \\
\hline $\mathrm{N}_{2}-140 \mathrm{~kg} \mathrm{~N} / \mathrm{ha}$ & 64.58 & 12.24 & 57.70 & 56,720 & 27,989 & 0.97 \\
\hline $\mathrm{N}_{3}-160 \mathrm{~kg} \mathrm{~N} / \mathrm{ha}$ & 70.29 & 14.82 & 64.30 & 60,672 & 31,645 & 1.09 \\
\hline SEm \pm & 0.70 & 0.14 & 1.66 & 855 & 855 & 0.03 \\
\hline $\mathrm{CD}(\mathrm{P}=\mathbf{0 . 0 5})$ & 2.82 & 0.56 & 6.68 & 3446 & 3446 & 0.12 \\
\hline \multicolumn{7}{|l|}{ Weed management } \\
\hline $\begin{array}{l}\text { W1 - Pyrazosulfuron@ } 25 \text { g/ha } \\
\text { (20 DAS) }\end{array}$ & 60.04 & 10.10 & 52.51 & 53507 & 27789 & 1.08 \\
\hline $\begin{array}{l}\text { W2 - Bispyribac sodium @ } 25 \\
\text { g/ha (20 DAS) }\end{array}$ & 66.12 & 12.27 & 57.84 & 58189 & 32446 & 1.26 \\
\hline $\begin{array}{l}\text { W3 - Pyrazosulfuron @25 g + } \\
\text { Bispyribac sodium @ } 25 \mathrm{~g} \\
\text { (tank mix) (20 DAS) }\end{array}$ & 69.27 & 13.65 & 61.75 & 60677 & 34059 & 1.28 \\
\hline $\begin{array}{l}\mathrm{W}_{4} \text { - Pendimethalin @1000 } \\
\text { g/ha }(\mathrm{PE}) f b \mathrm{~W}_{3}\end{array}$ & 72.35 & 14.65 & 65.17 & 62622 & 34338 & 1.21 \\
\hline $\begin{array}{l}\mathrm{W}_{5}-\text { Weed free }(2 \text { Hand } \\
\text { weeding at } 20 \text { and } 40 \text { DAS })\end{array}$ & 76.37 & 16.17 & 69.10 & 65277 & 24106 & 0.59 \\
\hline$W_{6}-$ Weedy check & 43.36 & 7.65 & 41.64 & 39230 & 14386 & 0.58 \\
\hline SEm \pm & 1.06 & 0.41 & 2.93 & 945 & 945 & 0.03 \\
\hline $\mathrm{CD}(\mathrm{P}=0.05)$ & 3.09 & 1.19 & 8.51 & 2741 & 2741 & 0.10 \\
\hline Interaction (NXW) & NS & NS & NS & NS & NS & NS \\
\hline
\end{tabular}


An experiment under split plot design replicated thrice, was conducted at University Research Farm of Dr. Rajendra Prasad Central Agricultural University, Pusa, Samastipur, Bihar during rainy season of 2016 to study the "Effect of weed management and nitrogen on weed dynamics and yield of rice under aerobic condition". The highest growth and yield attributes of rice were recorded under $160 \mathrm{~kg} \mathrm{~N} / \mathrm{ha}$ which was significantly superior to other nitrogen levels however, the highest grain yield of rice was recorded under $160 \mathrm{~kg} \mathrm{~N} / \mathrm{ha}$ which was statistically at par with $140 \mathrm{~kg} \mathrm{~N} / \mathrm{ha}$ and significantly superior to $120 \mathrm{~kg} \mathrm{~N} / \mathrm{ha}$. The highest net return was recorded by treatment $160 \mathrm{~kg} \mathrm{~N} / \mathrm{ha}$ which was significantly superior to other nitrogen levels. The highest value of Benefit: Cost ratio (1.09) was obtained under $160 \mathrm{~kg} \mathrm{~N} / \mathrm{ha}$ which was significantly superior to $140 \mathrm{~kg} \mathrm{~N} / \mathrm{ha} \& 120 \mathrm{~kg} \mathrm{~N} / \mathrm{ha}$. So, it may be concluded that application of $160 \mathrm{~kg} \mathrm{~N} / \mathrm{ha}$ can give better return in terms of yield as well as in economics too in rice under aerobic condition.

\section{Acknowledgement}

The authors gratefully acknowledge Dr. Rajendra Prasad Central Agricultural University, Pusa, Samastipur, Bihar for providing financial assistance and infrastructural facilities.

\section{References}

Azmi, M. and Baki, B. 2007. Weed flora landscapes and innovative management in direct seeded culture. Science, technology and trade for peace and prosperity. In: Proceedings of the $26^{\text {th }}$ International Rice Research Conference, 9-12 October, 2006, New Delhi, India. pp. 401-09.

Bhusan, L., Ladha, L. K. Gupta, R.K., Singh, S., Tirol Padre, A., Saharawat, Y.S.,
Gathala, M., Pathak, H. 2007. Saving of water and labor in rice-wheat with no tillage and direct seeding technologies. Agron. J. 99, 1288-1296.

Bouman, B. A.M., Peng, S., Castaneda, A. R. and Visperas, R.M. 2005. Yield and water use of irrigated tropical aerobic rice systems. Agril. Water Management 74: 87-105.

De Datta, S.K. 1981. Principles and practices of Rice production. John Wiley and Sons Publication, New York.618pp.

De Datta, S.K. and R.J. Buresh, 1989. Integrated nitrogen management in irrigated rice. Adv. Agron., 10: 143169.

Devi, G. and Sumathi, V. 2011. Effect of nitrogen management on growth, yield and quality of scented rice under aerobic conditions. Journal Research ANGRAU. 39(3):81-83.

Evans, L.T., Wardlaw, I.F. and Fischer, R.A. 1979. Wheat crop physiology. Blackie and Sons Publishers Pvt. Ltd., Bombay, pp. 101-135.

IWMI 2000. Comprehensive assessment of water management in agriculture Research report 2.

Jackson, M. L. 1973. Soil chemical analysis prentice hall of India Pvt. Ltd, New Delhi, India, pp: 134-204.

Jadhav, A.S., Solunke, S.S., Alse, U.N and Dhoble, M.V, 2006. Growth and yield contributing characters of upland basmati rice as influenced by irrigation and nitrogen. Annals of Plant Physiology. 20(1): 51-55.

Khan, A.W., R.A. Mann, M. Saleem and A. Majeed, 2012. Comparative rice yield and economic advantage of foliar KNO3 over soil applied K2SO4. Pak. J. Agric. Sci., 49: 481-484

Maheswari, J., Jaya Kumar Bose., Sangeetha, S.P., Sanjutha, S and Sathya Priya, R. 2008. Irrigaiton regimes and $\mathrm{N}$ levels influence chlorophyll, leaf area index, 
proline and soluble protein content of Aerobic rice. International Journal of Agricultural Research 34(4): 307-316.

Maity, S.K. and Mukherjee, P.K. 2008. Integrated weed management in dry direct seeded rainy season rice (Oryza sativa). Indian Journal of Agronomy 53 (2): 116-120.

Mishra, J.S. and Singh, V.P. 2011. Cultivar competitiveness and weed control in zero-till dry seeded irrigated rice (Oryza sativa). Indian Journal of Agricultural Sciences 81(10): 976-78.

Modgal, S.C., Y. Singh and P.C. Gupta, 1995. Nitrogen management in rice-wheat cropping system. Fert. News, 40: 4954.

Rao, A. N., Jounshon, D. E., Prasad. B., Ladh, J.K. and Mortimer, A. M. 2007. Weed management in direct seeded rice Advance in Agronomy 93:153-255.

Sathiya, C. and Ramesh. T. 2009. Effect of split application of nitrogen on growth and yield of aerobic rice. Asian Journals of Experimental Science 23(1): 303-306.

Singh, K and Tripathi, H.P. 2007. Effect of nitrogen and weed control practices on performance of irrigated direct seeded rice (Oryza sativa). Indian Journal of Agronomy 52(3): 231-234.

Tuong, T.P and Bouman, B.A.M.2003. Rice production in water scarce environments Tobe published in proceedings of the water productivity workshop, 12-14 Nov.2001, International Water Management Institute, Srilanka.

Thimmegowda, P., Govindappa, M., Kalyana Murthy, K.N., Shankaraiah, C. and Jnanesh, A.C. 2009. Effect of herbicides and cultural treatment on uptake of major nutrients by crop and weeds under aerobic rice cultivation. Journal of crop and weeds 5(1): 327-330.

Vlek, P.L.G. and B.H. Byrnes, 1986. The efficacy and loss of fertilizer $\mathrm{n}$ in lowland rice. In: Nitrogen Economy in Flooded Rice Soils, pp: 131-148.

Zhang, L., Lin, S., Bouman, B.A.M., Xue, C., Wei, F., Tao, H., Yang, H., Wang, D.Z. and Dittert, K. 2009. Response of aerobic rice growth and grain yield to $\mathrm{N}$ fertilizer at two contrasting sites near Beijing. China Field Crops. Research 114: 45-53

\section{How to cite this article:}

Neha Nandan, D. K. Roy, Shashank Kumar and Ashok Kumar. 2020. Effect of Nitrogen on Growth, Yield and Nutrient Uptake of Rice under Aerobic Condition. Int.J.Curr.Microbiol.App.Sci. 9(02): 2025-2035. doi: https://doi.org/10.20546/ijcmas.2020.902.231 